\title{
Analisis Konsekuensi Kualitas Pelayanan Tehadap Kepuasan Masyarakat (Kajian pada Pengguna Pelayanan Publik Dinas Perhubungan \& LLAJ Provinsi Jawa Timur)
}

\author{
Sukesi \\ Fakultas Ekonomi, Universitas Dr. Soetomo \\ E-mail: greenpct@yahoo.com
}

\begin{abstract}
A quality service and satisfying customer needs to be done continuously, despite complaints received is relatively low. Logical consequence of the perceived service quality will affect consumer behavior. This research aims to examine customer satisfaction and its consequences toward public service quality at Weigh Stations Services Unit at the Department of Transportation \& LLAJ East Java Province. The study was conducted in 11 UPT weigh stations by using a scale measuring 14 elements of service (U1-U14) which refers to the Minister for Administrative Reform No. KEP/25/M.PAN/2/2004 concerning the preparation of general guidelines for Community Satisfaction Index (HPI) Service Unit Government Agencies. Survey through questionnaires and indepth interview are used to collect the data. A total of 311 respondents with make use of descriptive statistics are used in the analysis method. This research finds that the public services quality of 11 weigh stations UPT in the Transportation Agency and the East Java Province LLAJ towards 14 service elements that were examined are generally classified in the category Good $(B)$ with an average value of $79.57(62.51-81.25)$.
\end{abstract}

Keywords: service quality, customer satisfaction, consequence

\section{PENDAHULUAN}

Sebuah organisasi usaha sudah seharusnya mampu menawarkan produk atau jasa yang berkualitas dan sustainable, karena mutu produk atau kualitas pelayanan yang diterima konsumen saat ini belum tentu diterima pula pada esok harinya. Begitu pula iklim layanan yang ada tidak sepenuhnya sesuai dengan yang diharapkan. Perubahan-perubahan yang terjadi di picu oleh berbagai faktor seperti: comparative advantage, global competition, dan government deregulation. Zeithaml et al. (1996) menyampaikan adanya suatu gap atau kesenjangan karena perbedaan persepsi jika kualitas layanan tersebut tidak diramu dengan baik, yaitu antara si pemberi jasa dengan pengguna jasa. Layanan yang bagus akan membuat pelanggan loyal, walau belum tentu berkorelasi lurus dengan produktivitas.

Di samping perbedaan dalam pengelolaan bisnis, perkembangan yang terjadi karena desakan lingkunganpun membawa implikasi yang sangat besar terhadap visi maupun manajemen perusahaan. Dalam peraturan tentang Otonomi Daerah (UU Nomor 22 Tahun 1999) terkandung beberapa prinsip dimana peran daerah memiliki otonomi yang nyata dan bertanggung jawab diharapkan semakin berarti. Prinsip ini memandang bahwa daerah mempunyai kewajiban untuk mensejahterakan masyarakatnya. Lebih lanjut satu fungsi utama dalam penyelenggaraan pemerintahan yang menjadi kewajiban apara- tur pemerintah adalah penyelenggaraan pelayanan publik.

Dewasa ini masih banyak dijumpai kelemahan dalam pelayanan publik oleh aparatur pemerintah sehingga belum dapat memenuhi kualitas yang diharapkan oleh masyarakat. Hal ini ditandai dengan masih adanya berbagai keluhan masyarakat yang disampaikan melalui berbagai media massa sehingga menimbulkan citra yang kurang baik terhadap kinerja aparatur pemerintah.

Di dalam hukum administrasi negara Indonesia, berdasarkan pengertian umum yang dimuat di dalam Lampiran 3 Keputusan Menteri Pendayagunaan Aparatur Negara No. 63/Kep/M.PAN/7/2003, paragraf I, butir $\mathrm{C}$, istilah "pelayanan publik" diartikan sebagai: "segala kegiatan pelayanan yang dilaksanakan oleh instansi pemerintah sebagai upaya pemenuhan kebutuhan orang, masyarakat, instansi pemerintah dan badan hukum maupun sebagai pelaksanaan ketentuan peraturan perundang-undangan". Pasal 3 Undang-undang No. 28 Tahun 1999 tentang Penyelenggaraan Negara yang Bersih dari Korupsi, Kolusi dan Nepotisme (selanjutnya UU KKN) menyebutkan asas-asas yang menjadi landasan penyelenggaraan pelayanan publik terdiri dari: asas kepastian hukum; asas tertib penyelenggaraan Negara; asas kepentingan umum; asas keterbukaan; asas proporsionalitas; asas profesionalitas; dan asas akuntabilitas. 
Berdasarkan Keputusan Menteri Pendayagunaan Aparatur Negara Nomor 25 Tahun 2004 bahwa pelayanan publik adalah segala kegiatan pelayanan yang dilaksanakan oleh penyelenggara pelayanan publik sebagai upaya pemenuhan kebutuhan penerima pelayanan, maupun dalam rangka pelaksanaan ketentuan peraturan perundang-undangan.

Salah satu upaya guna meningkatkan kualitas pelayanan publik, sebagaimana diamanatkan dalam Undang-undang Republik Indonesia Nomor 25 Tahun 2000 tentang Program Pembangunan Nasional (PROPENAS), perlu disusun Kajian Indeks Kepuasan Masyarakat sebagai tolok ukur untuk menilai tingkat kualitas pelayanan. Selain itu, data Kajian Indeks Kepuasan Masyarakat akan dapat menjadi bahan penilaian terhadap unsur pelayanan yang masih perlu perbaikan dan menjadi pendorong setiap unit penyelenggara pelayanan untuk meningkatkan kualitas pelayanannya.

Konsekuensi kualitas pelayanan terhadap kepuasan masyarakat merupakan data dan informasi tentang tingkat kepuasan masyarakat yang diperoleh dari hasil pengukuran secara kuantitatif dan kualitatif atas pendapat masyarakat dalam memperoleh pelayanan dari aparatur penyelenggara pelayanan publik dengan membandingkan antara harapan dan kebutuhannya.

Dewasa ini konsep kualitas telah menjadi suatu "tuntutan universal" dan telah menjadi faktor yang sangat dominan terhadap keberhasilan suatu organisasi. Quality mindset ini tidak saja diadopsi perusahaan jasa waralaba, tetapi telah menyebar ke perusahaan jasa pemerintah yang sifatnya nirlaba, yang selama ini resisten terhadap tuntutan akan kualitas layanan publik yang prima.

Hasil laporan yang disajikan sebagai rangkuman aktivitas Komisi Pelayanan Publik (KPP) Provinsi Jawa Timur selama kurun waktu Januari - Desember 2010 menunjukkan bahwa terdapat 176 pengaduan dimana yang sudah selesai ditangani 119, dalam proses klarifikasi 46 pengaduan, tidak dapat diproses 8 dan 3 bukan kewenangan KPP. Hasil KPP tersebut lebih bagus jika dibandingkan pada laporan kinerja KPP tahun 2009, yaitu Januari - Desember sebanyak 265 pengaduan, ini membuktikan masih perlunya peningkatan kualitas layanan. Sebab, jika dibuat grafis maka setiap bulan terdapat sekitar 22 pengadu yang melaporkan ketidakpuasannya pada instansi penyelenggara layanan publik.

Berkaitan dengan studi tentang kualitas layanan ini, kebanyakan peneliti terdahulu cenderung tertarik pada sikap pelanggan jasa perusahaan waralaba. Sementara penelitian terhadap konsekuensi perilaku dari pelayanan yang disampaikan kepada pelanggan jasa perusahaan publik seperti DLLAJR masih sedikit. Oleh karena itu, berangkat dari fenomena tersebut, penelitian ini diharapkan menemukan informasi untuk merumuskan suatu rekomendasi untuk meningkatan kualitas layanan yang lebih berarti. Kepuasan Masyarakat dan positioning keterkaitan antara atribut-atribut jenis pelayanan terhadap Unit Pelayanan Jembatan Timbang, dengan 11 Unit Pelayanan Terpadu Daerah (UPT) yang ada di Jawa Timur. Selain itu, juga dapat diketahui posisi kualitas pelayanan (service quality) setiap Unit Pelayanan Jembatan Timbang terhadap Unit Pelayanan Jembatan Timbang lainnya, berdasarkan atribut jenis pelayanan yang diberikan oleh aparatur pemerintah bagi para pengguna di Unit Pelayanan Jembatan Timbang.

Seperti diketahui keunikan pelayanan publik jembatan timbang yang menjadi kewenangan Dinas Perhubungan dan LLAJ Provinsi Jawa Timur di mana sering ditemukan pelanggaran khususnya kelebihan muatan yang kemungkinan telah melakukan tindakan-tindakan mempersulit, dan atau memperlambat atau bahkan menerapkan biaya yang kurang wajar atau memungut biaya yang tidak sesuai dengan ketentuan biaya yang telah ditetapkan. Dinas Perhubungan dan LLAJ Provinsi Jawa Timur harus berani melakukan evaluasi setiap saat, melakukan survey indepth konsumen.

Fenomena daya saing dalam era globalisasi yang kompetitif pada dasarnya akan berlaku pula bagi organisasi publik. Implikasinya, alternatif strategis yang perlu dilakukan dalam pengelolaan manajemen pelayanan adalah meningkatkan kemampuan kualitas pelayanan perusahaan (Gaspersz, 1997). Mengingat bahwa tuntutan pelanggan terhadap kualitas pelayanan semakin meningkat, kualitas jasa pelayanan yang diterima pelanggan saat ini belum tentu diterima di masa datang karena adanya perubahan selera pelanggan.

Konsumen yang tidak puas akan merasa kecewa, dan sesungguhnya mempunyai dua pilihan untuk menanggapi ketidakpuasan yang dirasakan yaitu dengan mengambil tindakan atau tidak mengambil tindakan. Dalam mengambil tindakan ini bisa pribadi atau pada pihak umum. Singh (1990) mengemukakan beberapa bentuk-bentuk pengambilan tindakan akibat dari ketidakpuasan konsumen yang terdiri dari tiga cara, yaitu: (1) Respon suara, misalnya meminta ganti rugi dari penjual, (2) Respon pribadi, misalnya komunikasi lisan yang negatif, dan (3) Respon pihak ketiga, misalnya mengambil tindakan hukum. Jika konsumen menggunakan respon suara untuk mengungkapkan ketidakpuasannya dengan komplain pada perusahaan, maka pihak perusahaan akan dapat langsung mengetahui apa yang menjadi 
keluhan konsumen sehingga masalahnya segera ditangani dan dicarikan jalan keluarnya. Tidak semua konsumen mengungkapkan ketidakpuasan mereka pada pihak perusahaan. Perusahaan mungkin beranggapan bahwa sedikitnya keluhan yang diterima merupakan cermin kepuasan konsumen atas pelayanan yang cukup baik. Padahal konsumen tidak puas tetapi tidak selalu disampaikan dalam bentuk keluhan langsung ke perusahaan, dan pelanggan yang diam ini jumlahnya seringkali lebih banyak. Tipe pelanggan seperti ini akan lebih berbahaya bagi perusahaan.

Berdasarkan latar belakang dan uraian tersebut, pokok permasalahan dalam penelitian ini dirumuskan sebagai berikut:

1 Bagaimanakah kualitas pelayanan jembatan timbang UPT terhadap kepuasan pengguna jembatan timbang di wilayah Dinas Perhubungan dan LLAJ Provinsi Jawa Timur?

2 Apakah kualitas pelayanan jembatan timbang UPT di wilayah Dinas Perhubungan dan LLAJ Provinsi Jawa Timur berpengaruh penting terhadap konsekuensi perilaku konsumen?

3 Bagaimanakah Indeks Kepuasan Masyarakat terhadap kinerja pelayanan jembatan timbang dan unit-unit pelayanan di Dinas Perhubungan dan LLAJ Provinsi Jawa Timur?

Sejalan dengan maksud dan permasalahan yang telah dikemukakan, maka penelitian ini diorientasikan pada pencapaian tujuan yaitu:

1. Untuk menganalisis ada tidaknya pengaruh kualitas pelayanan jembatan timbang UPT terhadap kepuasan pengguna jembatan timbang di wilayah Dinas Perhubungan dan LLAJ Provinsi Jawa Timur.

2. Untuk menguji sejauh mana kualitas pelayanan jembatan timbang UPT di wilayah Dinas Perhubungan dan LLAJ Provinsi Jawa Timur berpengaruh penting terhadap konsekuensi perilaku konsumen.

3. Untuk mengetahui Indeks Kepuasan Masyarakat terhadap kinerja pelayanan jembatan timbang dan unit-unit pelayanan di Dinas Perhubungan dan LLAJ Provinsi Jawa Timur.

\section{KAJIAN TEORITIS}

\section{Perilaku Konsumen}

Memahami tentang perilaku konsumen bukanlah pekerjaan yang mudah karena perilaku konsumen sangat kompleks dan sukar untuk diprediksi. Pendekatan-pendekatan yang selama ini banyak digunakan untuk menyikapi sikap, minat, dan perilaku konsumen mengasumsikan bahwa konsumen bersifat rasional dalam setiap pengambilan keputusannya (Kotler, 2003).

Perusahaan perlu mencari informasi semaksimal mungkin mengenai perilaku konsumen yang tidak dapat secara langsung dikendalikannya. Sampai saat ini, cara yang dipandang efektif untuk mempertahankan kelangsungan hidup organisasi bisnis adalah kemampuan organisasi dalam memberikan kepuasan bagi konsumennya karena apa yang disampaikan kepada konsumen akan selalu membawa konsekuensi berupa retensi maupun defeksi terhadap perusahaan. Perusahaan yang tidak dapat memenuhi kepuasan konsumennya akan sulit untuk berhasil. Seperti yang dikatakan oleh Assael (1995:6) bahwa kegagalan mengenali konsumen akan mengakibatkan kesalahankesalahan yang harus dibayar mahal.

Banyak definisi untuk menjelaskan tentang apa yang dimaksud dengan perilaku konsumen, diantaranya sebagai berikut:

1. Engel et al. (1995:4) menyatakan bahwa perilaku konsumen merupakan semua tindakan yang langsung terlibat dalam mendapatkan, mengkonsumsi, dan menghabiskan produk dan jasa, termasuk proses keputusan yang mendahului dan menyusuli tindakan ini,

2. Menurut Loudon \& Bitta (1993:5), perilaku konsumen adalah suatu "proses sampai pada keputusan dan aktivitas nyata individual yang bertalian dengan mengevaluasi, menginginkan, menggunakan, atau mengkonsumsi barang dan jasa”.

Berdasarkan kedua pendapat tersebut dapat disimpulkan bahwa perilaku konsumen adalah tindakan-tindakan yang dilakukan oleh individu, kelompok, atau organisasi yang berhubungan dengan proses pengambilan keputusan dalam mendapatkan, menggunakan barang-barang atau jasa yang dapat dipengaruhi oleh lingkungannya.

Engel et al. (1995:133) menyatakan model perilaku konsumen adalah menggambarkan sebuah rancangan untuk memeriksa efek-efek relatif dari sikap dan pengaruh sosial. Model adalah sebuah penyederhanaan gambaran dari kenyataan.

Berkaitan dengan perilaku konsumen, Engel et al. (1995:559) mengemukakan model pembelian seperti pada Gambar 1. Dari model tersebut tampak bahwa pada dasarnya proses keputusan konsumen mempunyai lima tahap, yaitu:

1. Mengidentifikasi masalah,

2. Pencarian alternatif terhadap pemecahan masalah,

3. Mengevaluasi alternatif-alternatif pemecahannya,

4. Mengambil keputusan atau memilih alternatif, dan

5. Mengevaluasi seberapa jauh alternatif yang sudah dipilih itu dapat mengatasi masalah (perilaku purna beli). 


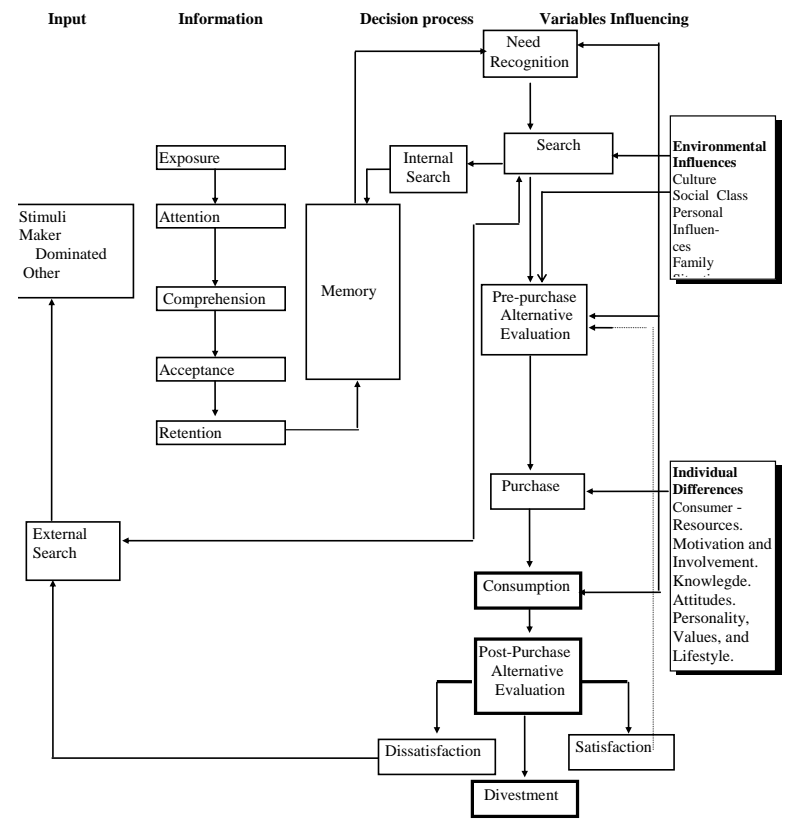

Sumber: Engel, Blackwell \& Miniard (1995:559)

Gambar 1. Model Pembelian dan Hasilnya

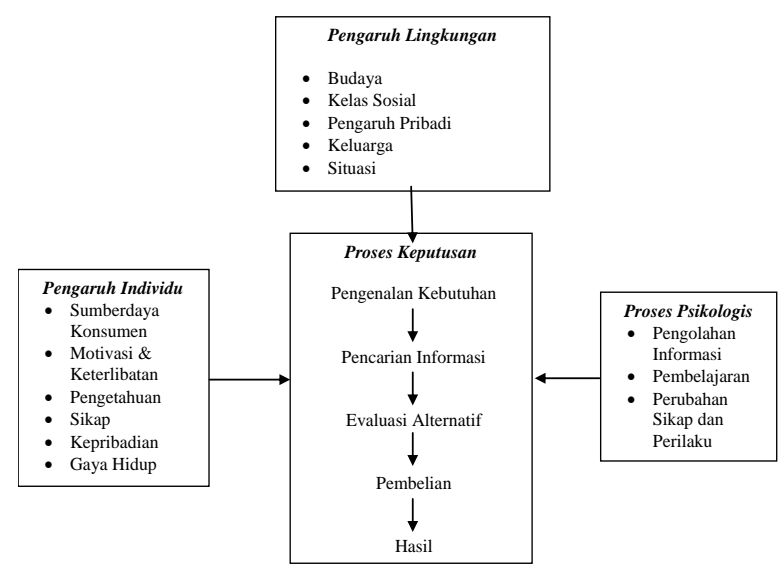

Sumber: Engel et al. (1995: 99)

Gambar 2. Faktor-faktor yang mempengaruhi perilaku konsumen

Gambar 1 tersebut menekankan bahwa perilaku konsumen itu dinamis. Ini berarti bahwa seorang konsumen, grup konsumen, serta masyarakat luas selalu berubah, dan bergerak sepanjang waktu. Hal ini merupakan suatu implikasi terhadap studi tentang perilaku konsumen. Engel et al. (1995) mengungkapkan kompleksitas faktor-faktor yang mempengaruhi dan membentuk perilaku proses keputusan seperti nampak pada Gambar 2.

\section{Kualitas Pelayanan}

Goetsch dan Davis dalam Tjiptono (1998) mengatakan kualitas merupakan suatu kondisi dinamis yang berhubungan dengan produk, manusia, proses dan lingkungan yang memenuhi harapan. Kualitas merupakan perwujudan atau gambarangambaran hasil yang mempertemukan kebutuhan dari pelanggan dalam memberikan kepuasan. Jadi konsep kualitas lebih dari sekedar memenuhi spesifikasi barang, kualitas mengimplikasikan memenuhi atau melebihi harapan tentang ketepatan waktu, akurasi pekerjaan, kecepatan tanggapan, dan unjuk kerja. Kualitas dipandang secara lebih luas, di mana tidak hanya aspek hasil saja yang ditekankan, melainkan meliputi proses, lingkungan, dan manusia.

Untuk mengukur kualitas layanan di sektor publik menurut Laterner \& Levine (1990) dan Hatry (1999) melalui 5 indikator, yakni:

1) Baik tidaknya layanan (quality of service). Baik tidaknya layanan dapat dilihat dari sejauh mana institusi dalam memberikan layanan publik dengan ramah, populis dan berbagai macam bentuk perilaku yang dapat menyenangkan dan memuaskan pelanggan.

2) Produktivitas (productivity). Produktivitas sering diukur dengan rasio antara input dengan output. Dalam konteks layanan publik produktivitas dapat diukur dengan jawaban pertanyaan.

3) Responsibilitas (responsibility). Responsibilitas, dapat dibatasi sebagai tanggung jawab secara intern institusi dan atau pelaksana layanan di dalam memberikan layanan publik atau menjalankan tugasnya.

4) Akuntabilitas (accountability). Akuntabilitas, dalam konteks layanan publik dapat dibagi menjadi dua sasaran: (a) bagi institusi pemerintah lokal dalam memberikan layanan publik; (b) bagi pelaksana layanan secara individual dimaknai dengan sejauhmana pelaksana layanan bertanggung jawab terhadap pekerjaan.

5) Responsivitas (responsiveness). Responsivitas diartikan sebagai daya peka organisasi dan pelaksana layanan dalam menyikapi perkembangan lingkungan institusinya.

\section{Prinsip-Prinsip Pelayanan Publik}

Sendi-sendi pelayanan menurut Keputusan Menteri Pendayagunaan Aparatur Negara nomor 63 tahun 2003 adalah sebagai berikut:

1) Kesederhanaan

2) Kejelasan dan kepastian

3) Keamanan

4) Akurasi

5) Tangung jawab

6) Kelengkapan sarana dan prasarana.

7) Kemudahan akses 
8) Kedisiplinan, kesopanan dan keramahan.

9) Kenyamanan

\section{Standar Pelayanan Publik}

Setiap penyelenggara pelayanan publik harus memiliki standar pelayanan dan dipublikasikan sebagai jaminan adanya kepastian bagi penerima pelayanan. Standar pelayanan merupakan ukuran yang dibakukan dalam penyelenggaraan pelayanan publik yang wajib ditaati oleh pemberi dan atau penerima pelayanan. Standar pelayanan publik menurut Keputusan Menpan Nomor 63 tahun 2003 terdiri dari:

1) Prosedur pelayanan

2) Waktu pelayanan

3) Biaya pelayanan

4) Produk pelayanan

5) Sarana dan prasarana

6) Kompetensi petugas pemberi pelayanan.

\section{Kepuasan Pemakai Pelayanan Publik}

Jembatan timbang dan unit pelayanan terpadu (UPT), sebagai bagian unit pelayanan publik, maka perlu melakukan pelayanan yang memuaskan pemakai/masyarakat.

Banyak definisi berkaitan dengan kepuasan pemakai (customer satisfaction) antara lain disebutkan oleh Tjiptono (2004) yang mengutip pendapat Day, bahwa kepuasan atau ketidakpuasan pelanggan adalah respon pelanggan terhadap evaluasi ketidaksesuaian/diskonfirmasi yang dirasakan antara harapan sebelumnya (atau norma kinerja lainnya) dan kinerja aktual produk yang dirasakan oleh pemakai. Dengan bahasa yang lebih sederhana Kotler (1997) menyebutkan kepuasan pelanggan sebagai: Tingkat perasaan seseorang setelah membandingkan kinerja (hasil) yang dirasakan dibandingkan dengan harapannya. Konsep kepuasan pemakai dapat dijelaskan pada Gambar 3.

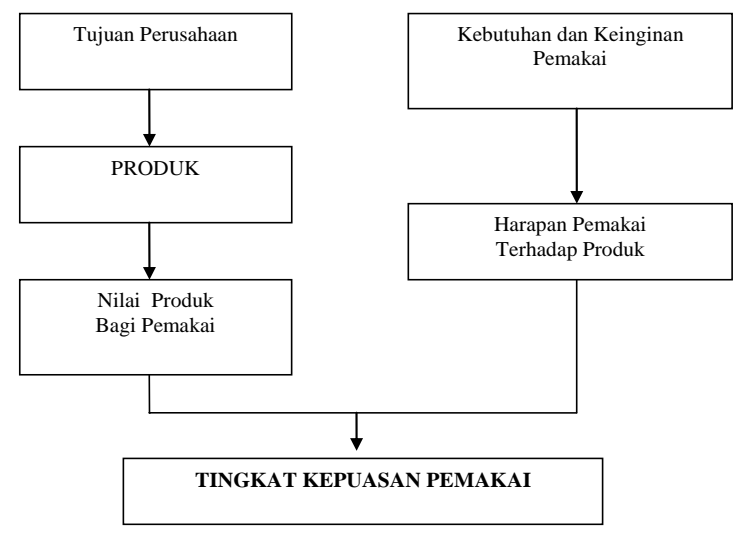

Sumber: Tjiptono (1998)

Gambar 3. Konsep Kepuasan Pemakai

\section{Kepuasan dan Ketidakpuasan Konsumen}

Kepuasan adalah tingkat perasaan seseorang setelah membandingkan kinerja/hasil yang dirasakannya dengan harapan. Menurut Engel et al. (1995) kepuasan konsumen merupakan evaluasi purna beli di mana alternatif yang dipilih sekurang-kurangnya memberikan hasil (outcome) yang sama atau melampui harapan konsumen, sedangkan ketidakpuasan timbul apabila hasil yang diperoleh tidak memenuhi harapan konsumen. Jadi tingkat kepuasan merupakan fungsi dari perbedaan antara kinerja yang dirasakan dengan harapan. Harapan pelanggan dapat dibentuk oleh pengalaman masa lampau, komentar dari kerabatnya serta janji dan informasi pemasar dan pesaingnya. Pelanggan yang puas akan setia lebih lama, mereka bersedia merekomendasi perusahaan, mau membayar sesuai mutu yang disampaikan, mengatakan hal-hal yang positif dari perusahaan, dan kurang sensitif terhadap harga.

Dari definisi-definisi tentang kepuasan tersebut adanya suatu kesamaan makna bahwa kepuasan pelanggan merupakan suatu penilaian emosional dari pelanggan setelah penggunaan suatu produk, di mana harapan dan kebutuhan terpenuhi.

Pelanggan yang tidak puas mereka akan kecewa, dengan kekecewaan itu pelanggan akan melakukan tindakan komplain, atau tidak sama sekali melakukan apa-apa (diam). Engel et al. (1995) mengemukakan bentuk-bentuk pengambilan tindakan akibat dari ketidakpuasan atas kualitas pelayanan yang disampaikan kepada pelanggan di antaranya:

1. Respon suara (voice response);

2. Respon pribadi (private response);

3. Respon pihak ketiga (third-party response);

Pencapaian kepuasan dapat merupakan proses yang sederhana ataupun kompleks, dan rumit. Dalam hal ini peranan setiap individu dalam service incounter sangatlah penting dan berpengaruh terhadap kepuasan yang dibentuk. Untuk dapat mengetahui tingkat kepuasan pelanggan secara lebih baik, maka perlu dipahami pula sebab-sebab kepuasan.

\section{Faktor-faktor yang Mempengaruhi Kepuasan dan Ketidakpuasan Konsumen}

Harapan pelanggan dibentuk dan didasarkan oleh beberapa faktor, di antaranya pengalaman berbelanja di masa lampau, opini teman dan kerabat, serta informasi dan janji-janji perusahaan, dan para pesaing (Kotler \& Armstrong, 1994: 198-199). Faktor-faktor tersebutlah yang menyebabkan harapan seseorang biasa-biasa saja atau sangat kompleks.

Cara perusahaan jasa untuk dapat tetap unggul bersaing adalah memberikan jasa dengan kualitas 
yang tinggi dari pesaingnya secara konsisten. Harapan pelanggan dibentuk oleh pengalaman masa lalunya, pembicaraan dari mulut ke mulut serta promosi yang dilakukan oleh perusahaan jasa, kemudian dibandingkannya.

Ada beberapa penyebab utama tidak terpenuhinya harapan pelanggan, penyebab tersebut ada yang bisa dikendalikan oleh penyedia jasa. Dengan demikian, penyedia jasa bertanggung jawab untuk meminimumkan miskomunikasi dan misinterpretasi yang mungkin terjadi dan menghindarinya dengan cara merancang jasa yang mudah dipahaminya dengan jelas. Dalam hal ini penyedia jasa harus mengambil inisiatif agar ia dapat memahami dengan jelas instruksi dari klien, dan klien mengerti benar apa yang akan diberikan.

Bagaimana dengan sifat-sifat dari pelanggan yang tidak puas tersebut. Ada beberapa faktor yang mempengaruhi seorang pelanggan yang tidak puas akan menyampaikan keluhannya atau tidak, seperti yang diuraikan Tjiptono (2004) sebagai berikut:

1. Derajat kepentingan konsumsi yang dilakukan

2. Tingkat ketidakpuasan pelanggan

3. Manfaat yang diperoleh

4. Pengetahuan dan pengalaman

5. Sikap pelanggan terhadap keluhan/komplain

6. Tingkat kesulitan dalam mendapatkan ganti rugi

7. Peluang keberhasilan dalam menyampaikan keluhan.

\section{Penelitian Terdahulu}

Beberapa penelitian sejenis yang telah dilakukan sebagai referensi dalam penelitian ini di antaranya:

1. Zeithaml et al. (1996) melakukan penelitian yang berjudul "The Behavioural Consequences of Service Quality". Dalam penelitian ini disajikan sebuah model konseptual tentang pengaruh service quality terhadap perilaku pelanggan perusahaan, yaitu apakah pelanggan tetap setia pada perusahaan atau meninggalkan perusahaan. Hasil kajian empiris dalam sebuah multi company yang berhubungan dengan tujuan perilaku pelanggan menunjukkan bahwa perilaku kesetiaan pelanggan dipengaruhi oleh service quality. Penemuan tersebut juga menunjukkan adanya perbedaan alami tentang quality intentions yang memiliki dimensi berbeda dengan behavioral intentions. Populasi dari penelitian Valarie dipakai untuk menguji hubungan antara kualitas layanan dengan behavioral intentions baik yang bersifat favorable maupun unfavorable. Di samping itu, penelitian ini mengungkap behavioral intentions yang ditunjukkan oleh konsumen berdasarkan pengalamannya mendapat masalah, dan penyelesaian masalah yang dialami pada saat mendapat layanan. Kuesioner dikirimkan kepada pelanggan dari sebuah perusahaan komputer, pelanggan retail chain, automobile insurer, dan life insurer. Tiap-tiap retail chain, automobile insurer, dan life insurer menyediakan sample random kepada 2400 pelanggan. Dalam model tersebut dimulai dari penilaian seorang konsumen terhadap suatu kualitas layanan. Jika penilaian konsumen terhadap kualitas layanan tinggi, maka behavioral intentions konsumen tersebut akan bersifat favorable (positif), karena dalam hal ini akan memperkuat hubungan positif dengan perusahaan, misalnya tetap loyal pada perusahaan, merekomendasikan perusahaan pada orang lain, meningkatkan volume pembeliannya atau bersedia membayar premium. Jika penilaian konsumen terhadap kualitas layanan rendah, maka behavioral intentions konsumen bersifat unfavorable (negatif), dan hubungannya dengan perusahaan kemungkinan lemah. Konsumen yang mempersepsikan kualitas layanan secara inferior kemungkinan akan menunjukkan perilaku pemutusan hubungan dirinya dengan perusahaan, dan akan melakukan komplain terhadap perusahaan. Behavioral intentions dapat dipandang sebagai indikator yang memberi tanda apakah konsumen akan tetap setia atau berpindah.

2. Dinas Perhubungan DLLAJ Provinsi Jawa Timur tahun 2009, melakukan penelitian dengan judul Indeks Kepuasan Masyarakat ditemukan data dan beberapa fakta hasil penelitian sebagai berikut:

1) Terdapat peningkatan Indeks Kepuasan Masyarakat pada Unit Pelayanan Jembatan Timbang dari tahun 2006 hingga tahun 2009. Terdapat peningkatan Indeks Kepuasan Masyarakat pada Unit Pelayanan Ijin Trayek dari tahun 2007 hingga tahun 2009. Terdapat penurunan Indeks Kepuasan Masyarakat pada Unit Pelayanan Uji Mutu dari tahun 2008 ke tahun 2009.

2) Indeks kepuasan masyarakat atas kualitas pelayanan pada seluruh unit pelayanan (jembatan timbang, ijin trayek, dan uji mutu) DISHUB dan LLAJ Provinsi Jawa Timur tergolong "Baik".

3) Unsur pelayanan terbaik pada unit pelayanan jembatan timbang adalah "Keamanan Pelayanan" terutama di "Jembatan Timbang Sedarum". Sedangkan unsur pelayanan terburuk adalah "Kewajaran biaya untuk mendapatkan pelayanan" terutama di "Jembatan Timbang Sedarum".

4) Unsur pelayanan yang sering dinilai baik adalah keamanan pelayanan dan yang sering dinilai kurang baik adalah kewajaran biaya untuk mendapatkan pelayanan dan kesesuaian antara biaya yang dibayarkan dengan biaya yang telah ditetapkan. 
5) Secara umum gambaran kondisi IKM di atas merefleksikan bahwa Indeks Kepuasan Masyarakat (IKM) cenderung mengalami kenaikan pada tahun 2006-2009, terutama pada unit pelayanan jembatan timbang di lingkungan Dinas Perhubungan dan LLAJ Provinsi Jawa Timur.

\section{METODE PENELITIAN}

\section{Jenis Penelitian}

Dalam kajian ini, jenis penelitian yang digunakan adalah penelitian berjenis kuantitatif yang bersifat deskriptif. Dimana, penelitian deskriptif menurut Sugiyono (2004) adalah penelitian yang dilakukan untuk mengetahui nilai variabel mandiri, baik satu variabel atau lebih, tanpa membuat perbandingan atau menghubungkan dengan variabel lain. Sedangkan Indriantoro (1999) menyatakan bahwa penelitian deskriptif merupakan penelitian terhadap masalahmasalah berupa fakta-fakta saat ini dari suatu populasi, di mana tujuan penelitian ini adalah untuk menguji hipotesis atau menjawab pertanyaan yang berkaitan dengan current opinion dari subjek yang diteliti. Sementara itu, Suryabrata (1997) menilai tujuan penelitian diskriptif adalah untuk membuat pencandraan secara sistematis, faktual, dan akurat mengenai fakta-fakta dan sifat-sifat populasi atau daerah tertentu.

\section{Kerangka Pemikiran}

Kerangka pemikiran yang disusun secara metodologis dengan tahapan-tahapan yang tergambar dalam bagan seperti Gambar 4 .

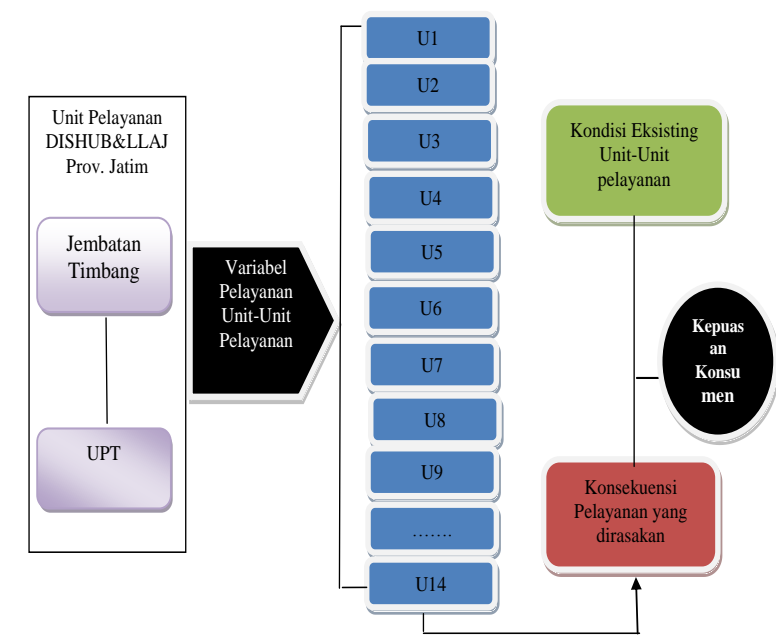

Gambar 4. Kerangka Berpikir Analisis Konsekuensi Kualitas Pelayanan Terhadap Kepuasan Masyarakat

\section{Variabel Penelitian}

Variabel dalam penelitian analisis konsekuensi kualitas pelayanan terhadap kepuasan konsumen di sini menggunakan acuan Keputusan Menteri Pendayagunaan Aparatur Negara Nomor KEP/25/ M.PAN /2/2004 tentang pedoman umum penyusunan Indeks Kepuasan Masyarakat (IKM) Unit Pelayanan Instansi Pemerintah untuk pengembangan instrumen sebagai unsur kepuasan masyarakat. Unsur-unsur yang dimaksud adalah:

1) Prosedur pelayanan (U1)

2) Kesesuaian waktu pelayanan (U2)

3) Kejelasan petugas pelayanan (U3)

4) Kedisipilinan petugas pelayanan (U4)

5) Tanggung Jawab petugas pelayanan (U5)

6) Kemampuan petugas pelayanan (U6)

7) Kecepatan pelayanan (U7)

8) Keadilan mendapatkan pelayanan (U8)

9) Keramahan dan kesopanan petugas (U9)

10)Kewajaran biaya pelayanan (U10)

11)Kepastian biaya pelayanan (U11)

12)Kepastian jadwal pelayanan (U12)

13)Kenyamanan lingkungan (U13)

14)Keamanan Pelayanan (U14)

Sedangkan variabel konsekuen masyarakat pengguna jembatan timbang diukur dengan beberapa unsur meliputi:

1) Bersedia membayar sesuai tarif yang ada;

2) Bersedia melakukan antrian dengan tertib;

3) Bersedia menyampaikan hal-hal yang baik;

4) Menyampaikan keluhan

Di mana dari beberapa variabel yang ada tersebut di atas akan disusun menjadi pertanyaanpertanyaan sebagaimana tercantum dalam kuisioner. Alternatif jawaban yang ditawarkan adalah 4 jawaban dengan menggunakan skala likert, dimana alternatif jawaban disusun secara bertingkat sesuai dengan skornya.

\section{Populasi Dan Penentuan Sampel}

Populasi dalam kajian ini meliputi seluruh masyarakat pengguna jasa (responden) di unit jembatan timbang di 11 Unit Pelaksana Teknis (UPT) yang ada di lingkungan Dinas Perhubungan dan Lalu Lintas Angkutan Jalan (LLAJ) Provinsi Jawa Timur meliputi:

1. UPT Probolinggo

2. UPT Jember

3. UPT Banyuwangi

4. UPT Surabaya

5. UPT Malang

6. UPT Bangkalan

7. UPT Lamongan/Bojonegoro 
8. UPT Mojokerto

9. UPT Kediri

10.UPT Tulungagung

11.UPT Madiun, dan,

Kajian ini menggunakan sampel untuk menjeneralisasi gejala yang ada dalam populasi, dimana penentuan sampelnya menggunakan accidental sampel dengan pengambilan sampelnya dilakukan dengan tehnik random sampling (acak) secara proporsional. Proses dalam penentuan populasi dan sampel adalah sebagai berikut: Peneliti mendatangi 11 UPT yang terdiri unit jembatan timbang yang telah ditentukan, kemudian melakukan koordinasi dengan pimpinan jembatan timbang yang bersangkutan untuk memdiskusikan tehnis pengambilan sampel sesuai dengan kriteria. Setelah ada kesepakatan diskusi, maka langkah selanjunya adalah implementasi pelaksanaan di lapangan, peneliti akan mendatangi langsung masyarakat yang sedang menggunakan jasa jembatan timbang saat itu, dan melakukan tanya jawab secara mendalam (indepth interview) dengan panduan kuisioner yang telah disiapkan. Sedangkan responden 11 Unit Pelaksana Teknis (UPT) dengan teknik random sampling (acak) secara proporsional terpilih.

Tabel 1. Jumlah Responden Terpilih

\begin{tabular}{cllc}
\hline No. & \multicolumn{1}{c}{ UPT } & \multicolumn{1}{c}{$\begin{array}{c}\text { Alamat Kab/Kota } \\
\text { Jembatan Timbang }\end{array}$} & $\begin{array}{c}\text { Jumlah } \\
\text { Responden }\end{array}$ \\
\hline 1. & di Jember & Kabupaten Jember & 40 \\
2. & di Surabaya & Kota Surabaya & 40 \\
3. & di Banyuwangi & Kabupaten Banyuwangi & 32 \\
4. & di Malang & Kabupaten Malang & 32 \\
5. & di Bangkalan & Kabupaten Bangkalan & 36 \\
6. & di Bojonegoro & Kabupaten Lamongan & 41 \\
7. & di Mojokerto & Kabupaten Mojokerto & 30 \\
8. & di Kediri & Kabupaten Kediri & 0 \\
9. & di Tulungagung & Kabupaten Tulungagung & 22 \\
10. & di Madiun & Kabupaten Madiun & 15 \\
11. & di Probolinggo & Kabupaten Probolinggo & 23 \\
\hline \multicolumn{2}{c}{} & \multicolumn{2}{c}{ Jumlah } \\
\hline
\end{tabular}

\section{Jenis dan Metode Pengumpulan Data}

Dalam kajian ini jenis data yang digunakan adalah data primer dan data sekunder. Metode dalam pengumpulan data primer, yang digunakan dalam kajian ini adalah dengan metode survey melalui penyebaran angket atau kuisioner. Sedangkan menurut Indriantoro (1999), metode survey merupakan metode pengumpulan data primer yang diperoleh secara langsung dari sumber aslinya, sehingga data yang diperoleh merupakan data yang menyatakan opini, sikap, pengalaman, atau karateristik subjek penelitian secara individual atau kelompok.

Sedangkan metode pengumpulan data sekunder, dalam penelitian ini direncanakan melalui beberapa sumber di antaranya adalah:

a. Studi Dokumentasi

b. Studi Kepustakaan

\section{Analisis Data}

Pengujian Kualitas Instrumen

1. Uji Reliabilitas

2. Uji Validitas

\section{Metode Analisa Data}

Kajian ini menggunakan metode analisa dengan statistik deskriptif di mana langkah-langkahnya meliputi:

1) Mencari nilai minimum dan maksimum dari jawaban responden pada tiap-tiap unsur pelayanan.

2) Menghitung nilai mean (rata-rata) dari jawaban responden pada tiap-tiap unsur pelayanan.

3) Menghitung nilai deviasi standar (standar simpangan baku) dari jawaban responden pada tiaptiap unsur pelayanan.

4) Menghitung nilai persentase masing-masing jawaban responden pada tiap-tiap unsur pelayanan.

5) Analisa kinerja unit pelayanan adalah analisa terhadap indikator-indikator pelayanan di Jembatan Timbang seperti kecepatan pelayanan, kemudahan proses, rasio jumlah pelayanan terhadap potensi pelayanan, dan lain sebagainya melalui pengamatan dan pengukuran secara langsung terhadap kondisi sebenarnya yang terjadi di masing-masing unit pelayanan.

6) Analisa kepuasan masyarakat merupakan ulasan terhadap hasil survey pengguna pelayanan di Jembatan Timbang yang akan ditampilkan dalam tabel-tabel dan grafik-grafik.

Scoring pada jawaban yang telah diisi oleh responden dengan kategorisasi: jawaban "a" diberi skor "1", jawaban "b" diberi skor "2", jawaban "c" diberi skor "3", dan jawaban "d" diberi skor "4"

Sedangkan entry data yang dilakukan adalah dengan cara memasukkan data hasil scoring tersebut di atas ke dalam tabulasi pada masing-masing unsur pelayanan. Dalam penghitungan indeks kepuasan masyarakat terhadap 14 unsur pelayanan yang dikaji, setiap unsur pelayanan memiliki penimbang yang sama dengan rumus sebagai berikut:

Bobot nilai rata-rata tertimbang

$$
=\frac{\text { Jumlah Bobot }}{\text { Jumlah Unsur }}=\frac{1}{14}=0,071
$$

Untuk memperoleh nilai tingkat kepuasan masyarakat digunakan pendekatan nilai rata-rata tertimbang dengan rumus sebagai berikut:

$$
I K M=\frac{\text { Total dari Nilai Persepsi per Unsue }}{\begin{array}{c}
\text { Total unsur yang terisi } \\
\text { penimbang }
\end{array}} \text { X Nilai }
$$


Untuk memudahkan interpretasi terhadap penilaian tingkat kepuasan yaitu antara 25-100 maka hasil penilaian tersebut di atas dikonversikan dengan nilai dasar 25 , dengan rumus sebagai berikut: IKM Unit pelayanan x 25

Tabel 2. Nilai Persepsi Kualitas Pelayanan dan Kinerja Unit Pelayanan

\begin{tabular}{ccccc}
\hline $\begin{array}{c}\text { Nilai } \\
\text { Persepsi }\end{array}$ & $\begin{array}{c}\text { Nilai } \\
\text { Interval }\end{array}$ & $\begin{array}{c}\text { Inilai } \\
\text { Interval } \\
\text { Konversi }\end{array}$ & $\begin{array}{c}\text { Mutu } \\
\text { Pelayan } \\
\text { an }\end{array}$ & $\begin{array}{c}\text { Kinerja } \\
\text { Unit } \\
\text { Pelayanan }\end{array}$ \\
\hline & $1,00-1,75$ & $25-43,75$ & D & Tidak baik \\
2 & $1,76-2,50$ & $43,76-62,50$ & C & $\begin{array}{c}\text { Kurang } \\
\text { baik }\end{array}$ \\
3 & $2,51-3,25$ & $62,51-81,25$ & B & Baik \\
4 & $3,26-4,00$ & $81,26-00,00$ & A & Sangat baik \\
\hline
\end{tabular}

\section{HASIL DAN PEMBAHASAN}

\section{Hasil Survey Pelayanan Jembatan Timbang Deket Lamongan}

Dari 11 UPT lokasi penelitian di bawah ini salah satu sampel UPT yang peneliti tampilkan yaitu jembatan timbang Deket Lamongan seperti terlihat pada Tabel 3, namun pembahasan telah merangkum 11 UPT yang menjadi lokasi kajian seperti terlihat pada Tabel 4. Kajian dan interpretasi hasil analisis sebagai berikut:

1) Penjelasan dan interpretasi kualitatif dari hasil Analisis Statistic Descriptive, kepuasan Masyarakat.

2) Menentukan unit pelayanan yang mana yang kualitasnya terendah (yang harus segera diperbaiki), dan item pelayanan yang mana yang kualitasnya terbaik (yang harus dipertahankan, dipelihara, dan lebih ditingkatkan lagi).

3) Mengetahui beberapa unsur konsekuensi masyarakat atas kualitas pelayanan yang dirasakan.

Berdasarkan hasil survey lapangan terhadap 41 responden pengguna Jembatan Timbang Deket, diketahui bahwa sebagian besar unsur pelayanan yang diberikan oleh petugas pelayanan Jembatan Timbang Deket termasuk kategori Sangat Baik (A). seperti terlihat pada Tabel 3 .

Dari Tabel 3 terlihat bahwa dari 14 unsur pelayanan di Jembatan Timbang Deket Lamongan, 8 unsur pelayanan termasuk kategori Sangat Baik (A), dan 6 unsur pelayanan yang lain termasuk kategori Baik (B). Dari 8 unsur pelayanan yang termasuk kategori Sangat Baik (A) tersebut yang hasil indeks nya tertinggi adalah unsur pelayanan keamanan (U14) dengan hasil indeks sebesar 93,93. Sedangkan 6 unsur pelayanan yang termasuk kategori Baik (B), unsur yang mempunyai hasil indeks terendah adalah unsur kemampuan petugas (U7) dengan nilai sebesar 75,54. Artinya, penilaian masyarakat pengguna pelayanan terhadap seluruh unsur pelayanan, secara rata-rata kepuasan masyarakat di Unit Pelayanan Jembatan Timbang Deket Lamongan termasuk kategori Sangat Baik (A) dengan nilai rata-rata sebesar 83,09.

Tabel 3. Kepuasan Masyarakat Unit Pelayanan Jembatan Timbang Deket

\begin{tabular}{|c|c|c|c|c|c|}
\hline No. & $\begin{array}{l}\text { Unsur Penilaian } \\
\text { Pelayanan }\end{array}$ & $\begin{array}{c}\text { Jumlah } \\
\text { Responden }\end{array}$ & $\begin{array}{l}\text { Skor } \\
\text { Rata- } \\
\text { Rata }\end{array}$ & $\begin{array}{c}\text { Hasil } \\
\text { Indeks }\end{array}$ & $\begin{array}{l}\text { Kualitas } \\
\text { Pelayanan }\end{array}$ \\
\hline 1 & $\begin{array}{l}\text { Kemudahan prosedur } \\
\text { pelayanan (U1) }\end{array}$ & 41.00 & 3.22 & 80.02 & B \\
\hline 2 & $\begin{array}{l}\text { Kesesuaian } \\
\text { persyaratan dgn } \\
\text { pelayanan (U2) }\end{array}$ & 41.00 & 3.09 & 76.79 & B \\
\hline 3 & $\begin{array}{l}\text { Kejelasan dan } \\
\text { kepastian petugas } \\
\text { (U3) }\end{array}$ & 41.00 & 3.25 & 80.76 & B \\
\hline 4 & $\begin{array}{l}\text { Kedisiplinan petugas } \\
\text { (U4) }\end{array}$ & 41.00 & 3.32 & 82.50 & A \\
\hline 5 & $\begin{array}{l}\text { Tanggung jawab } \\
\text { petugas (U5) }\end{array}$ & 41.00 & 3.50 & 86.98 & A \\
\hline 6 & $\begin{array}{l}\text { Kemampuan petugas } \\
\text { (U6) }\end{array}$ & 41.00 & 3.04 & 75.54 & B \\
\hline 7 & $\begin{array}{l}\text { Kecepatan pelayanan } \\
\text { (U7) }\end{array}$ & 41.00 & 3.18 & 79.02 & B \\
\hline 8 & $\begin{array}{l}\text { Keadilan } \\
\text { mendapatkan } \\
\text { pelayanan }(\mathrm{U} 8)\end{array}$ & 41.00 & 3.29 & 81.76 & A \\
\hline 9 & $\begin{array}{l}\text { Keramahan dan } \\
\text { kesopanan petugas } \\
\text { (U9) }\end{array}$ & 41.00 & 3.27 & 81.26 & A \\
\hline 10 & $\begin{array}{l}\text { Kewajaran biaya } \\
\text { pelayanan (U10) }\end{array}$ & 41.00 & 3.18 & 79.02 & B \\
\hline 11 & $\begin{array}{l}\text { Kesesuaian biaya yg } \\
\text { dibayar dg yang } \\
\text { ditetapkan (U11) }\end{array}$ & 41.00 & 3.39 & 84.24 & A \\
\hline 12 & $\begin{array}{l}\text { Kepastian jadwal } \\
\text { waktu pelayanan } \\
\text { (U12) }\end{array}$ & 41.00 & 3.65 & 90.70 & A \\
\hline 13 & $\begin{array}{l}\text { Kenyamanan di } \\
\text { lingkungan unit } \\
\text { pelayanan (U13) }\end{array}$ & 41.00 & 3.65 & 90.70 & A \\
\hline 14 & $\begin{array}{l}\text { Keamanan pelayanan } \\
\text { (U14) }\end{array}$ & 41.00 & 3.78 & 93.93 & A \\
\hline $\begin{array}{l}\text { Rat: } \\
\text { Tim }\end{array}$ & $\begin{array}{l}\text { a-Rata Unit Pelayana } \\
\text { bang }\end{array}$ & an Jembatan & & 83.09 & $\mathbf{A}$ \\
\hline
\end{tabular}

Sumber: Data Primer Hasil Kuisioner 2010, diolah

Artinya, hasil penilaian responden terhadap unit Pelayanan Jembatan Timbang Deket Lamongan berdampak pada konsekuensi perilaku dari kualitas pelayanan yang dirasakan. Hal ini tergambar dari hasil wawancara responden yang bersedia menyampaikan hal-hal yang berkesan baik seperti: petugasnya 
memberikan pelayanan dengan sabar, tidak mau diberi biaya melebihi tarif (angpou) jika terjadi kelebihan muatan, petugasnya bersikap santun, sehingga para pengguna yang terdiri para sopir-sopir beserta crew ini bersedia melakukan antrian dengan sabar jika terjadi antrian panjang, dan bahkan tempat ini menjadi tempat persinggahan/ampiran untuk tempat beristirahat jika para crew pengguna jembatan timbang tersebut mengalami kelelahan akibat perjalanan jauh.

Walaupun sebagaian besar responden terkesan bereaksi positif terhadap persepsi dari konsekuensi kualitas pelayanan yang dirasakan, namun dilihat dari fasilitas penunjang pelayanan publik jembatan timbang, terdapat beberapa fasilitas yang perlu dibenahi diantaranya adalah gudang penyimpanan barang dan lapangan penumpukan barang serta fasilitas jalan keluar dan masuk jembatan timbang. Adapun aspek SDM yang menyebabkan rendahnya kualitas pelayanan jembatan timbang tersebut diantaranya adalah kejelasan dan kepastian petugas (U3) serta keseuaian biaya yang dibayar dengan yang ditetapkan (U11). Para pengguna jembatan timbang pojok memberikan apresiasi yang baik terhadap pelayanan yang dilakukan oleh para petugas jembatan timbang. Selain pelayanan petugas yang relatif baik, juga telah didukung peralatan penunjang jembatan yang sudah cukup memadai. Demikian juga fasilitas penunjang lain seperti gedung operasional, lapangan parkir, jalan masuk dan keluar jembatan timbang serta gudang penyimpanan barang dalam kondisi baik. Seperti halnya fasilitas jembatan timbang Pojok yang perlu pembangunan/perbaikan adalah pagar, gedung untuk genset serta perambuan. Namun, kondisi seperti itupun para sopir-sopir beserta crew bisa dirasakan keakrabannya dalam beriteraksi.

Hasil penghitungan kepuasan masyarakat di 11 UPT jembatan timbang terhadap 14 unsur pelayanan yang dikaji, dengan setiap unsur pelayanan memiliki penimbang yang sama, selanjutnya dilakukan interpretasi terhadap penilaian tingkat kepuasan yaitu antara 25 - 100 maka hasil penilaian tersebut di atas dikonversikan dengan nilai dasar 25. Berdasarkan hasil penghitungan seperti pada tabel tersebut di atas, maka secara rinci rata-rata kepuasan masyarakat atas kualitas pelayanan dari ke 14 unsur pelayanan adalah sebagai berikut:

1. Kemudahan prosedur pelayanan (U1) yang paling tinggi diraih oleh UPT Jember sebesar 95,42. Sedangkan yang paling rendah dicapai oleh UPT Malang sebesar 74,55. Rata-rata indeks kepuasan masyarakat atas unsur pelayanan ini sebesar 82,35 yang tergolong Sangat Baik.

2. Kesesuaian persyaratan dengan pelayanan yang diterima (U2) yang paling tinggi diraih oleh UPT Surabaya sebesar 81,01 . Sedangkan yang paling rendah dicapai oleh UPT Tulungagung sebesar 69,08 Rata-rata indeks kepuasan masyarakat atas unsur pelayanan ini sebesar 77,73 yang tergolong Baik.

3. Kejelasan dan kepastian petugas yang melayani (U3) yang paling tinggi diraih oleh UPT Surabaya sebesar 88,47 . Sedangkan yang paling rendah dicapai oleh Banyuwangi sebesar 76,41 Rata-rata indeks kepuasan masyarakat atas unsur pelayanan ini sebesar 80,71 yang tergolong Baik.

4. Kedisiplinan petugas yang melayani (U4) yang

Tabel 4. Hasil Kualitas Pelayanan Jembatan Timbang di Dinas Perhubungan LLAJ Provinsi Jawa Timur Tahun 2010

\begin{tabular}{|c|c|c|c|c|c|c|c|c|c|c|c|c|c|c|c|c|c|c|c|c|c|c|c|c|}
\hline \multirow[b]{2}{*}{ No } & \multirow{2}{*}{$\begin{array}{l}\text { Unsur } \\
\text { Penilaian } \\
\text { Pelayanan }\end{array}$} & \multicolumn{2}{|c|}{ Probolinggo } & \multicolumn{2}{|c|}{ Jember } & \multicolumn{2}{|c|}{ Banyuwang } & \multicolumn{2}{|c|}{ Surabaya } & \multicolumn{2}{|c|}{ Malang } & \multicolumn{2}{|c|}{ Pamekasan } & \multicolumn{2}{|c|}{ Lamongan } & \multicolumn{2}{|c|}{ Mojokerto } & \multicolumn{2}{|c|}{ Kediri } & \multicolumn{2}{|c|}{ Tulungagun } & \multicolumn{2}{|c|}{ Madiun } & \multirow{2}{*}{$\begin{array}{c}\text { Rata2 } \\
\text { Nilai } \\
\text { Kepuasan }\end{array}$} \\
\hline & & $\begin{array}{l}\text { Rata2 } \\
\text { Skor }\end{array}$ & $\begin{array}{l}\text { Hasil } \\
\text { Indeks }\end{array}$ & $\begin{array}{l}\text { Rata2 } \\
\text { Skor }\end{array}$ & $\begin{array}{l}\text { Hasil } \\
\text { Indeks }\end{array}$ & $\begin{array}{l}\text { Rata2 } \\
\text { Skor }\end{array}$ & $\begin{array}{l}\text { Hasil } \\
\text { Indeks }\end{array}$ & $\begin{array}{l}\text { Rata2 } \\
\text { Skor }\end{array}$ & $\begin{array}{l}\text { Hasil } \\
\text { Indeks }\end{array}$ & $\begin{array}{l}\text { Rata2 } \\
\text { Skor }\end{array}$ & $\begin{array}{l}\text { Hasil } \\
\text { Indeks }\end{array}$ & $\begin{array}{l}\text { Rata2 } \\
\text { Skor }\end{array}$ & $\begin{array}{l}\text { Hasil } \\
\text { Indeks }\end{array}$ & $\begin{array}{l}\text { Rata2 } \\
\text { Skor }\end{array}$ & $\begin{array}{l}\text { Hasil } \\
\text { Indeks }\end{array}$ & $\begin{array}{l}\text { Rata2 } \\
\text { Skor }\end{array}$ & $\begin{array}{l}\text { Hasil } \\
\text { Indeks }\end{array}$ & $\begin{array}{l}\text { Rata2 } \\
\text { Skor }\end{array}$ & $\begin{array}{l}\text { Hasil } \\
\text { Indeks }\end{array}$ & $\begin{array}{l}\text { Rata2 } \\
\text { Skor }\end{array}$ & $\begin{array}{l}\text { Hasil } \\
\text { Indeks }\end{array}$ & $\begin{array}{l}\text { Rata2 } \\
\text { Skor }\end{array}$ & $\begin{array}{l}\text { Hasil } \\
\text { Indeks }\end{array}$ & \\
\hline 1 & U-1 & 3,58 & 88,96 & 3,63 & 90,21 & 3,31 & 82,25 & 3,84 & 95,42 & 3,00 & 74,55 & 3,20 & 79,52 & 3,10 & 77,04 & 3,05 & 75,79 & 0,00 & 0,00 & 3,00 & 74,55 & 3,43 & 85,24 & 82,35 \\
\hline 2 & U-2 & 3,22 & 80,02 & 3,25 & 80,76 & 3,13 & 77,78 & 3,26 & 81,01 & 3,00 & 74,55 & 3,24 & 80,51 & 3,00 & 74,55 & 3,10 & 77,04 & 0,00 & 0,00 & 2,78 & 69,08 & 3,30 & 82,01 & 77,73 \\
\hline 3 & U-3 & 3,22 & 80,02 & 3,27 & 81,26 & 3,06 & 76,04 & 3,56 & 88,47 & 3,16 & 78,53 & 3,28 & 81,51 & 3,19 & 79,27 & 3,10 & 77,04 & 0,00 & 0,00 & 3,17 & 78,77 & 3,47 & 86,23 & 80,71 \\
\hline 4 & $\mathrm{U}-4$ & 3,13 & 77,78 & 3,20 & 79,52 & 2,91 & 72,31 & 3,26 & 81,01 & 3,00 & 74,55 & 3,40 & 84,49 & 3,00 & 74,55 & 3,05 & 75,79 & 0,00 & 0,00 & 3,04 & 75,54 & 3,00 & 74,55 & 77,01 \\
\hline 5 & U-5 & 3,31 & 82,25 & 3,42 & 84,99 & 2,91 & 72,31 & 3,54 & 87,97 & 3,00 & 74,55 & 3,44 & 85,48 & 3,00 & 74,55 & 3,10 & 77,04 & 0,00 & 0,00 & 3,04 & 75,54 & 2,87 & 71,32 & 78,60 \\
\hline 6 & U-6 & 3,22 & 80,02 & 3,25 & 80,76 & 3,16 & 78,53 & 3,46 & 85,98 & 3,09 & 76,79 & 3,28 & 81,51 & 3,00 & 74,55 & 3,20 & 79,52 & 0,00 & 0,00 & 3,74 & 92,94 & 3,53 & 87,72 & 81,83 \\
\hline 7 & U-7 & 3,51 & 87,22 & 3,82 & 94,93 & 3,19 & 79,27 & 3,98 & 98,90 & 3,00 & 74,55 & 3,40 & 84,49 & 3,19 & 79,27 & 3,00 & 74,55 & 0,00 & 0,00 & 2,96 & 73,56 & 3,07 & 76,29 & 82,30 \\
\hline 8 & U-8 & 3,11 & 77,28 & 3,10 & 77,04 & 2,75 & 68,34 & 3,38 & 83,99 & 3,00 & 74,55 & 3,36 & 83,50 & 3,00 & 74,55 & 3,05 & 75,79 & 0,00 & 0,00 & 2,78 & 69,08 & 2,60 & 64,61 & 74,87 \\
\hline 9 & U-9 & 3,09 & 76,79 & 3,05 & 75,79 & 3,06 & 76,04 & 3,14 & 78,03 & 3,00 & 74,55 & 3,33 & 82,75 & 3,00 & 74,55 & 3,10 & 77,04 & 0,00 & 0,00 & 3,87 & 96,17 & 2,80 & 69,58 & 78,13 \\
\hline 10 & U-10 & 3,20 & 79,52 & 3,42 & 84,99 & 2,87 & 71,32 & 3,42 & 84,99 & 3,00 & 74,55 & 3,24 & 80,51 & 3,00 & 74,55 & 3,05 & 75,79 & 0,00 & 0,00 & 3,00 & 74,55 & 2,80 & 69,58 & 77,04 \\
\hline 11 & U-11 & 3,42 & 84,99 & 3,68 & 91,45 & 3,10 & 77,04 & 3,44 & 85,48 & 3,00 & 74,55 & 3,44 & 85,48 & 3,00 & 74,55 & 3,25 & 80,76 & 0,00 & 0,00 & 2,87 & 71,32 & 2,80 & 69,58 & 79,52 \\
\hline 12 & U-12 & 3,29 & 81,76 & 3,20 & 79,52 & 3,03 & 75,3 & 3,2 & 79,52 & 3,00 & 74,55 & 3,48 & 86,48 & 3,00 & 74,55 & 3,15 & 78,28 & 0,00 & 0,00 & 2,74 & 68,09 & 3,33 & 82,75 & 78,08 \\
\hline 13 & U-13 & 3,09 & 76,79 & 3,02 & 75,05 & 3,06 & 76,04 & 3,28 & 81,51 & 3,00 & 74,55 & 3,52 & 87,47 & 3,00 & 74,55 & 3,40 & 84,49 & 0,00 & 0,00 & 3,39 & 84,24 & 3,53 & 87,72 & 80,24 \\
\hline 14 & U-14 & 3,93 & 97,66 & 3,95 & 98,16 & 3,03 & 75,3 & 3,94 & 97,91 & 3,00 & 74,55 & 3,40 & 84,49 & 3,00 & 74,55 & 3,55 & 88,22 & 0,00 & 0,00 & 3,13 & 77,78 & 3,50 & 86,98 & 85,56 \\
\hline & $\begin{array}{l}\text { Rata2 Nilai } \\
\text { Kepuasa }\end{array}$ & 3,31 & 82,22 & 3,38 & 83,89 & 3,04 & 75,56 & 3,48 & 86,44 & 3,02 & 74,99 & 3,36 & 83,44 & 3,03 & 75,40 & 3,15 & 78,37 & 0,00 & 0,00 & 3,11 & 77,23 & 3,15 & 78,15 & 79,57 \\
\hline
\end{tabular}


paling tinggi diraih oleh UPT Pamekasan sebesar 84,49 Sedangkan yang paling rendah dicapai oleh UPT Banyuwangi sebesar 72,13 Rata-rata indeks kepuasan masyarakat atas unsur pelayanan ini sebesar 77,01 yang tergolong Baik.

5. Tanggung jawab petugas yang melayani (U5) yang paling tinggi diraih oleh UPT Surabaya sebesar 87,97 Sedangkan yang paling rendah dicapai oleh UPT Madiun sebesar 71,32 Rata-rata indeks kepuasan masyarakat atas unsur pelayanan ini sebesar 78,60 yang tergolong Baik.

6. Kemampuan petugas dalam melayani (U6) yang paling tinggi diraih oleh UPT Tulungagung sebesar 92,94 Sedangkan yang paling rendah dicapai oleh UPT Lamongan sebesar 74,55 Ratarata indeks kepuasan masyarakat atas unsur pelayanan ini sebesar 81,83 yang tergolong Sangat Baik.

7. Kecepatan pelayanan (U7) yang paling tinggi diraih oleh UPT Jember sebesar 94,93 Sedangkan ang paling rendah dicapai oleh UPT Tulungagung sebesar 73,56 Rata-rata indeks kepuasan masyarakat atas unsur pelayanan ini sebesar 82,30 yang tergolong Sangat Baik.

8. Keadilan untuk mendapatkan pelayanan (U8) yang paling tinggi diraih oleh UPT Bangkalan sebesar 83,50 Sedangkan yang paling rendah dicapai oleh UPT Madiun sebesar 64,61 Rata-rata indeks kepuasan masyarakat atas unsur pelayanan ini sebesar 74,87 yang tergolong Sangat Baik.

9. Keramahan dan kesopanan petugas dalam melayani (U9) yang paling tinggi diraih oleh UPT Tulungagung sebesar 96,17 Sedangkan yang paling rendah dicapai oleh UPT Madiun sebesar 69,58 Rata-rata indeks kepuasan masyarakat atas unsur pelayanan ini sebesar 78,13 yang tergolong Baik.

10. Kewajaran biaya untuk mendapatkan pelayanan (U10) yang paling tinggi diraih oleh UPT Jember sebesar 84,99 Sedangkan yang paling rendah dicapai oleh UPT Madiun sebesar 68,58 Rata-rata indeks kepuasan masyarakat atas unsur pelayanan ini sebesar 77, 04 yang tergolong Baik.

11. Kesesuaian antara biaya yang dibayarkan dengan biaya yg telah ditetapkan (U11) yang paling tinggi diraih oleh UPT Jember sebesar 91,45 Sedangkan yang paling rendah dicapai oleh UPT Madiun sebesar 69,58 Rata-rata indeks kepuasan masyarakat atas unsur pelayanan ini sebesar 79,52 yang tergolong Baik.

12. Ketepatan pelaksanaan dengan jadwal waktu pelayanan (U12) yang paling tinggi diraih oleh UPT Madiun sebesar 82,75 Sedangkan yang paling rendah dicapai oleh UPT Tulungagung sebesar 68,09 Rata-rata indeks kepuasan masya- rakat atas unsur pelayanan ini sebesar 78,08 yang tergolong Baik.

13. Kenyamanan di lingkungan unit pelayanan (U13) yang paling tinggi diraih oleh UPT Madiun sebesar 87,72 Sedangkan yang paling rendah dicapai oleh UPT Malang sebesar 74,55 Rata-rata indeks kepuasan masyarakat atas unsur pelayanan ini sebesar 80,24 yang tergolong Baik.

14. Keamanan pelayanan (U14) yang paling tinggi diraih oleh UPT Surabaya sebesar 97,91 Sedangkan yang paling rendah dicapai oleh UPT Malang sebesar 74,55 Rata-rata indeks kepuasan masyarakat atas unsur pelayanan ini sebesar 85,56 yang tergolong Sangat Baik.

\section{Pembahasan}

Berdasarkan ringkasan hasil survey di lokasi penelitian diketahui bahwa secara umum kepuasan masyarakat pengguna jembatan timbang pada masing-masing Jembatan Timbang pada tahun 2010 mengalami kenaikan dibandingkan dengan hasil kinerja kualitas pelayanan pada tahun-tahun sebelumnya (hasil penelitian sebelumnya). Artinya, terdapat beberapa faktor yang menyebabkan terjadinya peningkatan kinerja tersebut, yaitu SDM petugas pelayanan serta sarana dan fasilitas penunjang jembatan timbang yang tersedia. Sehingga kepuasan yang bisa dirasakan langsung responden berdampak kepada perilaku yang positif. Konsekuensi logis masyarakat sebagai pengguna merasakan pelayanan yang bernilai, kepuasan pelanggan merupakan suatu penilaian emosional dari pelanggan secara langsung setelah merasakan, di mana harapan dan kebutuhan terpenuhi.

Dari aspek Sumber Daya Manusia, adanya peningkatan kualitas pelayanan yang diberikan oleh para petugas jembatan timbang yang menyangkut antara lain prosedur pelayanan, persyaratan pelayanan, kecepatan pelayanan, kedisiplinan petugas, keramahan dan kesopanan petugas, serta berbagai pelayanan lainnya. Sedangkan faktor fisik yang terkait dengan sarana dan fasilitas pelayanan penunjang admininstrasi jembatan timbang, dan peningkatan peralatan dan fasilitas fisik penunjang jembatan timbang lainnya yang nyata antara lain adalah:

1. Pembangunan gudang/perbaikan jalan masuk/ keluar jembatan timbang

2. Pembangunan pagar depan jembatan timbang;

3. Pembangunan tempat parkir;

4. Perbaikan kantin dan urugan jembatan timbang Trowulan;

Mengapa kualitas pelayanan tersebut mengalami peningkatan dibandingkan tahun sebelumnya (hasil 
penelitian sebelumnya), ada beberapa kondisi dari hasil kualitas kinerja yakni adanya peningkatan hasil kualitas kinerja jembatan timbang yang sudah bersertifikasi ISO dan jembatan timbang yang belum bersertifikasi ISO. Dari 11 unit jembatan timbang tersebut yang sudah mendapatkan sertifikasi ISO sebanyak 6 unit jembatan timbang, sisanya 5 unit jembatan timbang belum bersertifikasi ISO.

Meskipun pelayanan publik jembatan timbang Lamongan dan jembatan timbang Mojoagung tersebut belum memiliki sertifikasi ISO, namun dalam memberikan pelayanan kepada para pengguna telah memenuhi standar ISO, sehingga para pengguna jembatan timbang di kedua unit jembatan timbang tesebut merasa puas. Selain itu, secara fisik peralatan penunjang yang ada di kedua jembatan timbang tersebut masih relatif cukup baik. Kondisi tersebut berbeda dengan unit pelayananan jembatan timbang Trowulan. Meskipun jembatan timbang Trowulan telah mendapatkan sertifikasi ISO pada tahun 2007 lalu, namun menurut hasil survey IKM jembatan timbang Trowulan memiliki indeks terendah diantara jembatan timbang yang lain, yakni sebesar 68,55 (B). Faktor penyebab rendahnya IKM jembatan timbang Trowulah tersebut, selain faktor fasilitas penunjang jembatan timbang yang kurang memadai, juga disebabkan oleh faktor SDM pelayanan jembatan timbang tersebut.

Dilihat dari fasilitas penunjang pelayanan publik jembatan timbang, terdapat beberapa fasilitas yang perlu dibenahi diantaranya adalah gudang penyimpanan barang dan lapangan penumpukan barang serta fasilitas jalan keluar dan masuk jembatan timbang. Adapun aspek SDM yang menyebabkan rendahnya IKM jembatan timbang tersebut diantaranya adalah kejelasan dan kepastian petugas (U3) serta keseuaian biaya yang dibayar dengan yang ditetapkan (U11).

Konsekuensi responden sangat terkesan dengan kualitas pelayanan yang penuh keakraban, intensitas komunikasi, dan kualitas komunikasi yang diberikan para petugas jembatan timbang tersebut di atas. Selain faktor fisik yang berupa sarana dan fasilitas jembatan timbang, juga didukung oleh SDM yang dirasakan telah sesuai dengan yang diharapkan oleh para pengguna jembatan timbang tersebut, sehingga para pengguna merasa puas atas atas pelayanan yang diberikan petugas dan memberikan apresiasi yang baik atas pelayanan yang diberikan. Sebaliknya jembatan timbang Baureno, meskipun telah mendapatkan sertifikasi ISO pada tahun 2009, berdasarkan hasil survey mempunyai Hasil Indeks terendah diantara 6 jembatan timbang yang termasuk kategori $\mathrm{B}$, dengan nilai indeks sebesar 75,62. Rendahnya hasil indeks jembatan timbang Baureno lebih banyak disebabkan faktor pelayanan yang dilakukan oleh petugas jembatan timbang terutama yang berkaitan dengan persyaratan pelayanan (U2), keadilan mendapatkan pelayanan (U8), kepastian jadwal waktu pelayanan (U12) serta kenyamanan di lingkungan unit pelayanan (U12). Selain faktor pelayanan petugas jembatan timbang, fasilitas penunjang pelayanan jembatan timbang yang perlu peningkatan/perbaikan pagar keliling jembatan timbang dan perambuan.

Adapun jembatan timbang yang termasuk kategori C (sebanyak 3 unit jembatan timbang) semuanya belum mendapatkan sertifikasi ISO. Meskipun belum mendapatkan sertifikasi ISO, satu dari tiga unit jembatan timbang tersebut kualitas pelayanannya sangat memuaskan (A) yaitu jembatan timbang Pojok dengan hasil indeks sebesar 82,82. Para pengguna jembatan timbang pojok memberikan apresiasi yang baik terhadap pelayanan yang dilakukan oleh para petugas jembatan timbang. Selain pelayanan petugas yang relatif baik, jembatan timbang pokok tersebut juga telah didukung peralatan penunjang jembatan yang sudah cukup memadai. Demikian juga fasilitas penunjang lain seperti gedung operasional, lapangan parkir, jalan masuk dan keluar jembatan timbang serta gudang penyimpanan barang dalam kondisi baik. Fasilitas jembatan timbang pojok yang perlu pembangunan/perbaikan adalah pagar, gedung untuk genset serta perambuan. Dari tiga jembatan timbang yang termasuk kategori $\mathrm{C}$ ini, yang hasil kualitas pelayanannya tersendah adalah jembatan timbang Jrengik dengan hasil indeks sebesar 77,14. Masih rendahnya hasil kinerja kualitas pelayanan jembatan timbang jrengik ini dapat dipahami, karena jembatan timbang jrengik masih relative baru, sehingga paralatan dan fasilitas penunjang jembatan timbang masih terbatas dan perlu penambahan/perbaikan.

Respon positif yang disampaikan pengguna jembatan timbang, merupakan bukti dari konsekuensi kualitas pelayanan yang dirasakan. Hasil penilaian responden terhadap unit Pelayanan Jembatan Timbang sangat berdampak pada konsekuensi perilaku dari kualitas pelayanan yang dirasakan. Hal ini tergambar dari hasil wawancara responden yang bersedia menyampaikan hal-hal yang berkesan baik seperti: petugasnya memberikan pelayanan dengan sabar, tidak mau diberi biaya melebihi tarif (angpou) jika terjadi kelebihan muatan, petugasnya bersikap santun, pelayanan yang diberikan tetap responsive walau melayani antrian yang panjang, sehingga para pengguna yang terdiri para sopir-sopir beserta crew ini mau melakukan antrian dengan sabar jika terjadi antrian panjang, dan bahkan tempat ini menjadi tempat persinggahan/ampiran untuk tempat ber- 
istirahat jika para crew pengguna jembatan timbang tersebut mengalami kelelahan akibat perjalanan jauh.

Terdapat peningkatan Indeks Kepuasan Masyarakat (IKM) pada Unit Pelayanan Jembatan Timbang pada tahun 2010 yaitu 79.57. Pada tahun 2009, indeks kepuasan masyarakat (IKM) di unit pelayanan jembatan timbang mengalami sedikit kenaikan dengan nilai rata-rata 69,58 (Baik), dibandingkan dengan periode sebelumnya tahun 2008, yaitu rata-rata 68.74) (Baik), artinya meningkatnya kepercayaan dan kepuasan masyarakat atas unit pelayanan tersebut. Untuk tahun 2010 hal ini ditunjukkan oleh peningkatan indeks kepuasan masyaraka (IKM)-nya yang cukup signifikan. Sedangkan 6 unit jembatan timbang yang termasuk kategori B, yang sudah bersertifikasi ISO sebanyak 2 unit, yaitu jembatan timbang Baureno dan jembatan timbang Klakah. Dari 5 unit jembatan timbang yang termasuk ketegori A yang kualitas pelayanannya sangat baik (A) adalah jembatan timbang Besuki dengan hasil indeks sebesar 81,79. Jembatan Timbang Besuki, meskipun belum mendapatkan sertifikat ISO, mempunyai kualitas kinerja sangat tinggi, karena telah dilengkapi dengan peralatan penunjang dan fasilitas penunjang jembatan timbang yang relatif memadai.

\section{KESIMPULAN}

\section{Kesimpulan}

Berdasarkan hasil analisis deskriptif data survey dapat disimpulkan beberapa hal sebagai berikut:

1. Kualitas pelayanan publik pada jembatan timbang di lingkungan DISHUB dan LLAJ Provinsi Jawa Timur yaitu dari 11 UPT jembatan timbang terhadap 14 unsur pelayanan yang dikaji secara umum tergolong dalam katagori "Baik (B)" dengan nilai rata-rata 79.57 (62.51-81.25). Dari 11 UPT jembatan timbang tersebut, yang sudah mendapatkan sertifikasi ISO sebanyak 6 unit jembatan timbang, sisanya 5 unit jembatan timbang belum bersertifikasi ISO.

2. Kualitas pelayanan berpengaruh terhadap kepuasan pengguna jembatan timbang, yang secara konsekuensi berdampak terhadap perilaku dengan ditunjukkan oleh tingkat loyalitas dengan kesediaan untuk membayar sesuai dengan layanan yang disampaikan, respon positif yang disampaikan pengguna jembatan timbang merupakan bukti dari konsekuensi kualitas pelayanan yang dirasakan. Lebih lanjut tergambar dari hasil wawancara responden yang bersedia menyampaikan hal-hal yang berkesan baik seperti: petugasnya memberikan pelayanan dengan sabar, tidak mau diberi biaya melebihi tarif (angpou) jika terjadi kelebihan muatan.

3. Terdapat peningkatan yang signifikan Indeks Kepuasan Masyarakat (IKM) pada Unit Pelayanan Jembatan Timbang pada tahun 2010 yaitu 79.57, artinya meningkatnya kepercayaan dan kepuasan masyarakat atas unit pelayanan pada tahun 2010. Untuk tahun 2009 Indeks Kepuasan Masyarakat (IKM) di unit pelayanan jembatan timbang dengan nilai rata-rata 69,58 (Baik), dibandingkan dengan periode sebelumnya tahun 2008, yaitu rata-rata 68.74 (Baik).

\section{Saran}

Ada beberapa saran yang peneliti sampaikan agar kualitas pelayanan yang sudah tertata ini minimal bisa dipertahankan antar lain:

1. Segala pelanggaran harus harus ditindak sesuai dengan aturan yang berlaku;

2. Sopir yang melanggar mempunyai beking, sehingga sulit ditindak. Oleh karena itu solusi sederhana petugas harus tegas dalam menerapkan peraturan;

3. Peningkatan fasilitas penunjang jembatan timbang berupa peningkatan perambuan dan pembangunan pagar di jembatan timbang;

4. Banyak pengemudi yang melanggar batas muatan sudah dikompensasi pada JT sebelumnya, sehingga tidak bisa dikompensasi lagi, sehingga sosialisasi kepada sopir/pengusaha tentang Undang-Undang No. 2 tahun 2009 perlu ditingkatkan;

5. Sarana (komputer) untuk memberikan pelayanan kompensasi sebagian besar sudah tua dan sering eror sehingga layanan sering terganggu. Oleh karena itu, perlu penggantian/peremajaan komputer yang representatif untuk mendukung kelancaran operasional Jembatan Timbang.

\section{DAFTAR PUSTAKA}

Alwy, Syaffaruddin. 2001. Manajemen Sumber Daya Manusia: Strategi Keunggulan Kompetitif, Cetakan pertama, Yogyakarta: BPFE-Yogyakarta.

Assael. 1995. Consumer Behavior and Marketing Action, Fourth Edition, Boston: PWS-Kent Publishing Company.

Cook, Colleen \& Fred Heath. 2000. User's Perception of Library Service Quality: A LIBQUAL Qualitative Study, Washington DC: ARL Measuring Service Quality Symposium 
www.arl.org/libqual/event/oct2000msq/papers/ HeatCook/heatcook.html

David, Osborne \& Ted Gaebler. 2005. Mewirausahakan Birokrasi, Jakarta: PPM.

Engel, J.F., Roger D. Blackwell \& P.W. Miniard. 1995. Perilaku Konsumen, Buku Dua, Edisi Keenam, Jakarta: Binarupa Aksara.

Fernandes, Joe dkk. 2002. Otonomi Daerah di Indonesia Masa Reformasi: Antara Ilusi dan Fakta, Jakarta: IPOS dan Ford Fondation.

Gaspersz, V. 1997. Manajemen Kualitas: Penerapan Konsep-Konsep Kualitas Dalam Manajemen Bisnis Total, Jakarta: Penerbit PT Gramedia Pustaka Utama.

Hatry, Harry P. 1999. Performance Measurement: Getting Results, Second Edition, Urban Institute Press.

Indriantoro, Nur \& B. Supomo. 1999. Metodologi Penelitian Bisnis, Yogyakarta: BPFE-Yogyakarta.

Kertajaya, Hermawan, The 10 Credos of Compassionate Marketing, www.markplusnco.com.

Kotler, Philip \& Gary Armstrong. 1994. Principles of Marketing, Sixth Edition, New Jersey: Prentice Hall.

Kotler, Philip. 1997. Manajemen Pemasaran: Analisis, Perencanaan, Implementasi, dan Pengendalian, Edisi Keenam, Jilid Dua, Terjemahan Ancella Anitawati, Jakarta: Penerbit PT. Prenhalindo.

Kotler, Philip. 2003. Manajemen Pemasaran, Edisi Millennium, Buku Satu, Jakarta: Penerbit Salemba Empat.

2003. Manajemen Pemasaran, Edisi Millennium, Buku Dua, Jakarta: Penerbit Salemba Empat.

Laterner \& Levine. 1993. Strategic Planing for Public, Terjemahan oleh Budiono, Jakarta: Hastabuana.

Loudon, David L. \& Albert J. Della Bitta. 1993. Consumer Behavior: Concepts and Applications, McGraw-Hill.

Moenir, H.A.S. 2002. Manajemen Pelayanan Umum di Indonesia. Jakarta: Bumi Aksara J.

Nurgiyantoro, Burhan \& Gunawan Marzuki. 2000. Statistik Terapan Untuk Penelitian Ilmu-Ilmu Sosial, Cetakan Pertama, Jogyakarta: Gadjah Mada University Press.
Propenko, Yoseph \& Pavlin Igor. 1991. Enterpreneurship Development in Public Enterprise, London: Englewood.

Ratminto \& Atik Septi Winarsih. 2005. Manajemen Pelayanan: Pengembangan Model Konseptual, Penerapan Citizen's Chapter dan Standar Pelayanan Minimal, Jogjakarta: Pustaka Pelajar.

Renborg, Greta. 1997. Marketing Library Service: How It All Began (s.1.) 63 ${ }^{\text {rd }}$ IFLA General Conference (www.ifla.org/IV/ifla63reng.htm).

Riyanto, Yatim. 2007. Metodologi Penelitian Pendidikan Kualitatif dan Kuantitatif, Surabaya: Unesa University Press.

Singh, Jagdip, Spring. 1990. "A Typology of Consumer Dissatisfaction Response Styles", Journal of Retailing, Vol. 66 (1), page 57-99.

Trahn, Isabella, Jennifer Croud, John Hayward, \& Karen Kealy. June 2001. "Analysing the Quality Gap: Reflections on Results from an Australasian Universitas 21 Libraries Standard Survey of Service quality", Australian Academic and Research Libraries, 32(2), page 93109.

Singarimbun, Masri \& Sofyan Effendi. 1989. Metode Penelitian Survei, Edisi Revisi, Jakarta: LP3ES.

Suryabrata, Sumadi. 1997. Metodologi Penelitian. Jakarta: RajaGrafindo Persada.

Santoso, Singgih. 2005. Statistik Deskriptif: Konsep dan Aplikasi dengan Microsoft Excel dan SPSS, Jogyakarta: Andi Offset.

Sugiyono. 2004. Metode Penelitian Bisnis, Bandung: Alfabeta.

Singarimbun, Masri \& Sofyan Effendi. 1989. Metode Penelitian Survei, Edisi Revisi, Jakarta: LP3ES.

Tjiptono, Fandy \& Anastasia Diana. 1998. Total Quality Manajemen, Yogyakarta: Andi Offset.

Tjiptono, Fandy. 2004. Manajemen Pemasaran Jasa, Yogyakarta: Andi Offset.

Wahyudi, Kumorotomo. 2005. Akuntabilitas Birokrasi Publik: Sketsa Pada Masa Transisi, Jogjakarta: MAP-UGM dan Pustaka Pelajar.

, Keputusan Menteri Pendayagunaan Aparatur Negara Nomor 25 Tahun 2004 tentang Pedoman Umum Penyusunan Indeks Kepuasan Masyarakat Unit Pelayanan Instansi Pemerintah. 
Peraturan Pemerintah Daerah Nomor 11 Tahun 2005 tentang Pelayanan Publik di Jawa Timur.

Peraturan Pemerintah Daerah Nomor 14 Tahun 2006 tentang Implementasi Pelayanan Publik di Jawa Timur.

, Undang-Undang Nomor 25 Tahun 2009 tentang Pelayanan Publik.

, Undang-Undang Nomor 14 Tahun 2008 tentang Keterbukaan Informasi Publik.
Kajian Indeks Kepuasan Masyarakat (IKM) Tahun 2009. Surabaya: Dishub dan LLAJ Provinsi Jawa Timur.

Zeithaml, Valarie A., Leonard L. Berry \& A. Parasuraman. April 1996. "The Behavioral Consequences of Service Quality", Journal of Marketing, Vol. 60, page 31-46.

Zeithaml, Valarie A. \& Mary Jo Bitner. 1996. Service Marketing, Mcgraw-Hill International Edition. 